\title{
Socio-economic Benefits of Wind Power in Brazil
}

\author{
Moana Simas $^{1}$, Sergio Pacca ${ }^{2}$ \\ ${ }^{1}$ Energy Graduate Programme \\ University of Sao Paulo, Sao Paulo, Brazil \\ e-mail: moana@usp.br \\ ${ }^{2}$ School of Arts, Sciences, and Humanities \\ University of Sao Paulo, Sao Paulo, Brazil
}

Cite as: Simas, M., Pacca, S., Socio-economic Benefits of Wind Power in Brazil, J. sustain. dev. energy water environ. syst., 1(1), pp 27-40, 2013, http://dx.doi.org/10.13044/j.sdewes.2013.01.0003

\begin{abstract}
Investments in renewable energy and climate change mitigation go beyond the reduction of greenhouse gas emissions. Secondary benefits include technology transfer, reduction in emissions of other pollutants, and job creation, often called green jobs. It is known that job creation reflects on social, economic, environmental and territorial aspects. Therefore, it can be an indicator of social performance of energy projects. Wind power has experienced an explosive growth over the past few years, and projects contracted between 2009 and 2011 will increase Brazilian installed capacity by $450 \%$ in 2016 . This article evaluates the potential consequences of this rapid growth on job creation in Brazil. Jobs were quantified in manufacturing, installation and operation stages, observing national manufacture of major components. Estimated wind power growth will generate 90,000 jobs from 2012 till 2016. Over 74\% of the jobs are created in the construction and operation stages, which have high level of local employment, bringing social and economic benefits to the installation sites.
\end{abstract}

\section{KEYWORDS}

Wind power, employment, socio-economic benefits, sustainable development, renewable energy technologies, local development

\section{INTRODUCTION}

Investing in a low-carbon economy creates risks and opportunities. According to Frankhauser et al [1], the most important benefit from climate and renewable energy policies is innovation, which demands technical change adapted to a new market structure. In addition, the quest for new technologies and processes increases the demand for skilled labor.

Employment generation driven by renewable energy promotion has been discussed, and is seen as a new driver for the deployment of clean energy technologies. This debate has been seen, for example, in the United States, as can be perceived in a speech given by President Barack Obama, on June 15, 2010: "As we recover from this recession, the transition to clean energy has the potential to grow our economy and create millions of jobs - but only if we accelerate that transition. Only if we seize the moment."[2].

According to the United Nations Environmental Program (UNEP), green jobs are labour in various activities that contribute to preserving or restoring environmental quality, including jobs created in renewable energy technologies (RET) [3]. Most studies reveal that RET are more labor-intensive than fossil fuel-based power generation [4-6]. Hence, the substitution of RET for fossil fuels leads to a net positive effect on employment.

Global employment in the RET sector was above 2.3 million in 2006. Brazil is one of the most significant RET employers, with 500,000 jobs in the biomass sector, due to its 
large scale sugarcane ethanol industry. Globally, wind energy generated 300,000 jobs up to 2006, and it is expected that employment in this sector will reach 2.1 million in 2030 [3].

Previous studies on employment have shown that manufacturing is responsible for the majority of direct employment in the wind power sector [6-10], having a noticeable effect on employment rates. In addition, employment rates are indicators for the stage of the sector in a specific region and time, including the development stage of the technology and its national components manufacture. Thus, it cannot be applied to different contexts. Consequently, it is necessary to evaluate employment generation considering local conditions of the wind power industry and market.

Wind power is growing rapidly in Brazil. Projects contracted between 2009 and 2011 will add $6.7 \mathrm{GW}$ of wind capacity to the power matrix, which will start generation by the end of 2016, raising total wind power capacity to $8.1 \mathrm{GW}$ in 2016. This growth will result in a 450\% increase in five years, compared to $1.5 \mathrm{GW}$ installed in December 2011. The effects of this growth on employment generation have not been assessed so far.

This article aims to quantify the short run employment generation potential of the wind power sector in Brazil. First, a review of social and economic benefits of renewable energy at national and, especially, at regional and local levels, is presented. Then, a picture of the evolution and prospects for wind power in Brazil is given, followed by the methodology and assumptions used to evaluate job creation in the Brazilian wind power sector from 2012 to 2016. Finally, the results are described, and the article closes with a discussion of the main results.

\section{SOCIAL AND ECONOMIC BENEFITS OF RENEWABLE ENERGY TECHNOLOGIES}

Environmental benefits brought by RET have been widely assessed, as well as economic costs and its contribution to energy security. However, a thorough discussion of the socio-economic impacts of these technologies is still scarce. This discussion becomes even more important in periods of low economic growth [1,7]. Among the major socio-economic benefits are technological innovation and industrial development; distributed generation and universal access to energy; regional and local development, especially in rural areas; and job creation.

According to Laitner et al. [11], assessments on the performance of climate and energy policies usually do not take into account the dynamics of technological innovation, and often associate reductions in energy consumption and GHG emissions with economic losses. Rather, innovation and diffusion of clean and efficient technologies can lead to net gains in the economy. Technological innovation should be seen beyond the immediate horizon, and should be encouraged by policies that reduce institutional and market barriers for new technologies. Frankhauser et al. [1] argue that technological innovation and the creation of new opportunities for investments and economic growth are both consequences of climate policies. Technological change and innovation, in the long term, increase the demand for labour and skills. The authors also emphasize the role of good policies aimed at motivating technological innovation. In this context, the pioneers in the development of clean technologies have the potential for regional leadership. The authors use the case of Germany, which today stands out as a leader in the export of clean technologies.

RET are capital intensive, and most of the investment is concentrated in the initial phase of the project - the cost of wind turbines and other equipment can account for about $75 \%$ of the total investment of a wind farm [12]. Thus, implementation of renewable energy projects tends to offer an opportunity for developing equipment industries for domestic consumption and even for export $[1,13,14]$. 
In developing countries, energy consumption per capita is usually lower than in developed ones, since the former are undergoing development and expansion of goods and services production and consumption, as well as reducing inequalities in access to energy. The inclusion of renewable energy and energy efficient technologies early in the development process accelerates the efficient use of resources, called leapfrogging, enabling development processes with lower environmental impacts [15]. The adoption of renewable energy development projects can meet the development goals without going through the intensity of fossil fuel consumption that marked the growth in developed countries [16].

The convergence between the fields of energy planning and economic development is present in various energy policies, such as the American Recovery and Reinvestment Act of 2009, an economic investment program in the US, in which investments of $\$ 50$ billion targeted both innovative energy technologies and job creation. Such convergence is known as energy-based economic development, whose main goals are to increase self-sufficiency and energy diversification, contributing to economic and industrial growth and development; to increase entrepreneurship and encourage technological innovation; and to increase the level of employment and training [17].

The increased self-sufficiency and energy diversification, at the sub-national level, expands regional competitiveness and offers potential for the creation and retention of jobs, especially when the focus is on renewable energy. Economic growth refers to the creation or expansion of economic activity, which leads to increased employment, income, GDP, local supply of goods and services, and tax collection. Economic development adds focus to the qualitative aspects of quantitative economic growth, such as the diversification of the regional economy, workforce training, and improving education and quality of life.

All these aspects depend on the availability of skilled workers. The increased capacity should allow workers to reach the required skills to meet the necessary job requirements for the implementation of new technologies. RET companies and governments should ally to identify the short and long terms demands for skilled work at regional level and expand training courses, thus supporting local job opportunities in RET. This requires cooperation between the public and private planning of education and business. The presence of renewable energy projects in rural areas, especially those characterized by low economic development, can bring benefits to the community. High unemployment rates, lack of alternative economic development, and high rates of migration of economically active population, offer a worthwhile environment for investment in RET.

Compared to traditional power plants, renewable energy units are often smaller, modular and decentralized and, therefore, they are often located in rural areas with low population density. Due to this feature, the construction of these plants demands high amounts of labour, and creates the potential for training and employment of rural populations in several locations [18]. Besides generating temporary jobs in construction, there are fewer but long lasting job opportunities in the operation and maintenance $(\mathrm{O} \& \mathrm{M})$ of power plants. The deployment of renewable energy projects offers an alternative or complement to agricultural activities, and contributes to rural development [12]. Even though the number of jobs created in one location is not significant for the country, it might be regionally meaningful [19]. A study by Bergmann et al. [13] in Scotland showed that the rural population awareness regarding RET social benefits has increased, and is significantly higher than that from urban population.

Another important aspect is land leasing by wind farms. Because wind turbines occupy only a small fraction of the area, the revenue from land renting can be invested in other productive activities in the property $[12,20]$. Besides the landowners and the workers in construction and O\&M, other stakeholders benefit from renewable energy 
projects. During the construction stage there is an increase in demand of goods and services, such as lodging and meals, due to the crew involved in the work. Suppliers of goods and services within communities can benefit from the project's installation, which increases total income of the community and creates temporary job opportunities. Depending on the project, other compensations such as school reforms and public infrastructure improvements also take place [12].

A summary of regional and local development benefits brought by investment in renewable energy sources is illustrated in Figure 1.

Despite the potential to bring numerous benefits to the local and regional development, the incentive to renewable energy should not be considered as a development policy, but if applied in conjunction with other social policies, it can contribute to the local development of these communities [19].

Job creation is a key issue for the evaluation of economic development in a region. A concept that has been gaining ground in discussions of social and economic benefits in a low carbon economy is that of green jobs. According to UNEP [3], green jobs are those that contribute to preserving or restoring environmental quality. These jobs are located in diverse industries and include jobs in energy efficiency, clean technologies, efficient use of natural resources, and activities in low-GHG emissions.

A discussion of job creation in RET, which gained momentum in the early 2000s, began due to uncertainties about the effectiveness of public policies for renewable energy and its effects on the economy, especially those based on heavy governmental subsidies.

In addition to quantifying jobs and socio-economic impacts either locally or nation-wide, training and technological bottlenecks faced by the renewable energy sector also deserve attention. Studies with companies in the wind sector in the European Union have identified a lack of qualified professionals, especially for positions that require a higher training level $[8,9]$.

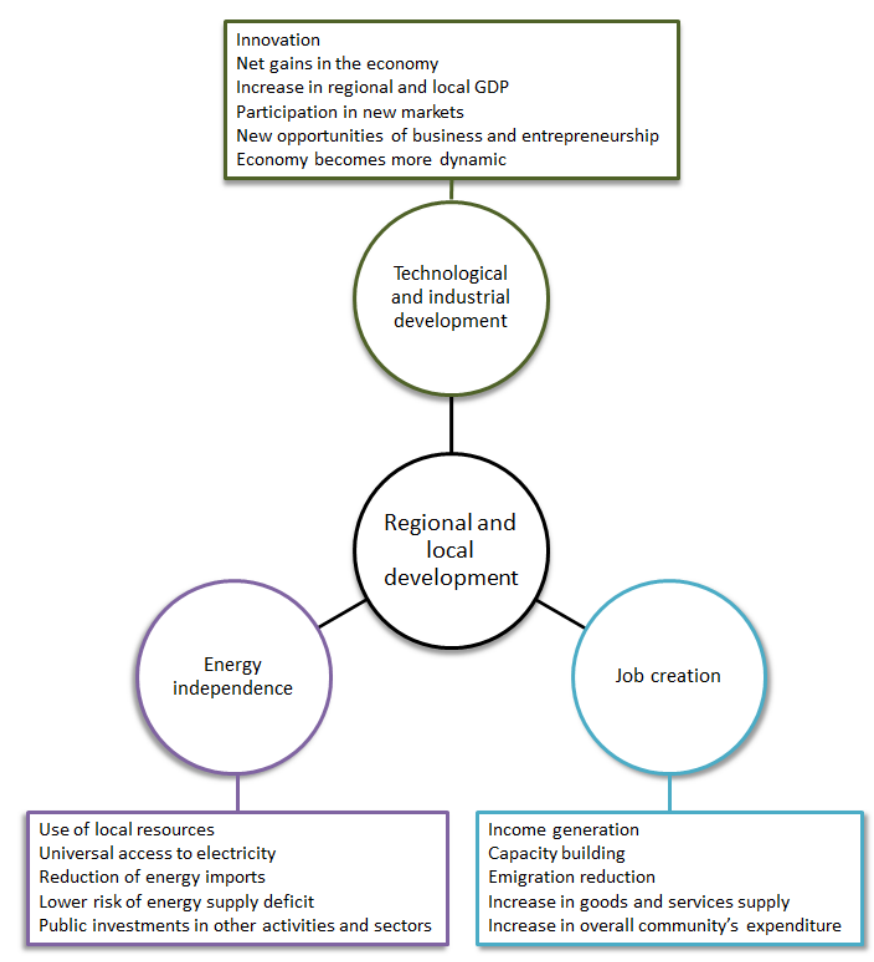

Figure 1. Regional and local aspects of RET. Own elaboration from [12,17,20,21] 
Jobs generated by wind power and other RET can be grouped into three categories according to their location, temporal nature, and level of expertise. The first category refers to jobs generated in technological development, and includes R\&D and equipment manufacturing. The second category refers to jobs in installation and decommissioning of plants, and comprises planning, project management, transportation and power plant construction and decommissioning. The third category is operation and maintenance $(\mathrm{O} \& \mathrm{M})$, and includes, besides the actual O\&M of the plant, energy distribution and commercialization. The characteristics are summarized in Table 1.

Table 1. Classification and characteristics of employment in RET [21]

\begin{tabular}{|c|c|c|c|c|}
\hline Category & $\begin{array}{l}\text { Volume of job } \\
\text { creation }\end{array}$ & Location $^{(1)}$ & $\begin{array}{l}\text { Temporal } \\
\text { nature }\end{array}$ & $\begin{array}{l}\text { Specialization level } \\
\text { demanded }\end{array}$ \\
\hline $\begin{array}{l}\text { Technological } \\
\text { development }\end{array}$ & Medium & $\begin{array}{l}\text { From non-local to } \\
\text { local }\end{array}$ & Stable & Very high \\
\hline $\begin{array}{l}\text { Installation/ } \\
\text { decommissioning }\end{array}$ & High & $\begin{array}{l}\text { From local to } \\
\text { non-local }\end{array}$ & Temporary & High \\
\hline $\begin{array}{l}\text { Operation and } \\
\text { maintenance }\end{array}$ & Low & Local & Stable & Medium \\
\hline
\end{tabular}

(1) From higher to lower probability

Two approaches might be explored to improve the creation and maintenance of local jobs. The first one is bringing innovation and technological development to the regional level, which creates highly qualified stable jobs. The second one is investing in capacity building, increasing the number of local workers in installation and decommissioning and decreasing the amount of workers brought from elsewhere. Employees' training is a key issue for renewable energy development [21].

At the same time, because most of the local jobs generated by wind power is temporary, i.e., during the installation of the project, policies aiming to maintain the stream of new projects each year should be considered.

\section{WIND ENERGY IN BRAZIL}

Brazil was the pioneer Latin American country to install a wind turbine in the early 1990s. However, over the next ten years, little progress was made in the consolidation of wind energy as an alternative power generation technology, mainly due to the high cost of the technology, associated with the lack of incentive policies. In 2001 was published the Atlas of the Brazilian Wind Potential, which estimated the technical available capacity in the country as $143 \mathrm{GW}$ [22]. According to the inventory, the main areas for harnessing wind energy resources are the Northeast, Southeast and South, which together account for about $90 \%$ of all Brazilian wind power potential.

The electricity mix in Brazil is one with the greatest share of renewable sources in the world. Early in the second quarter of 2012, the capacity of power generation from renewable sources accounted for $79.3 \%$, and the share of hydropower was greater than 70\%. In 2011 hydroelectric plants accounted for more than 90\% of the electricity generation in the country. In addition, most of the electricity imported by Brazil also comes from hydropower. Thus, incentives for renewable energy in Brazil aim to diversify the energy matrix and maintain the dominant share of RET, providing energy security, decreasing environmental impacts of large hydro expansion, encouraging the development of new industries, and creating jobs. Nevertheless, because of recent climate conditions compromising operation of hydropower plants and estimates of 
growing electricity demand, the Brazilian government has been discussing the addition of higher levels of fossil fuels power plants to ensure the energy supply.

Besides the great untapped wind potential in the country and its location often in areas of low population density, wind power has another advantage for the Brazilian grid. Electricity generation in hydroelectric plants is subject to seasonal hydrologic regimes. Although wind generation is also seasonal, it is complementary to hydropower $[23,24]$. Thus, the inclusion of large amounts of wind power in predominantly hydroelectric systems can result in accumulation of energy in the reservoirs, optimizing their use and increasing energy reliability and mitigating drought impacts [25].

After an energy shortage period between 2001 and 2002 due to low reservoir levels, the inclusion of wind power in the energy planning scope became more evident. The Incentive Program for Alternative Sources of Electric Energy (PROINFA), launched in 2004, sought the inclusion of wind energy, biomass and small hydroelectric plants (SHP) in the Brazilian matrix. With the installation of new plants, the Ministry of Mines and Energy (MME) was targeting also non-energy goals, such as leveraging the domestic equipment industry, generating jobs, and reducing GHG emissions [26].

The results of the program were noticeable and enabled the consolidation of wind power as an energy alternative in Brazil. PROINFA paved the way for the establishment of the wind turbines industry in the country. Although initially the requirement of a $60 \%$ national share in the equipment installed led to the delay of several projects, it encouraged the emergence of a supply chain for wind turbines in the country.

PROINFA was the main engine to drive the development of the wind market in Brazil. As the first effective public policy targeting the sector, it provided an environment with minimal risk to the investment in a technology yet uncommon in the country. The program showed that wind energy is technically feasible, and served as learning experience for the various activities related to this sector. The availability of long-term energy sale contracts with the public utility Eletrobras at a rate that reflects the capital costs, the Brazilian Bank of Development (BNDES) special financing terms up to $80 \%$ of the project's investment cost, and the generation flexibility, resulted in an attractive environment for investors.

Although PROINFA enclosed other energy sources, SHP and biomass were already common to the electricity market several years before the program. Nevertheless, the policy was decisive for the emergence of wind power. Due to the new environment and little knowledge, there were natural barriers such as the lack of skilled labour, lack of experience from project developers and from environmental licensing agencies, technical problems, shortage of domestic equipment to fulfil the domestic content requirements, and high costs. Another obstacle that PROINFA faced was the difficulty in obtaining funding from retail investors due to bureaucracy and collateral requirements, which many entrepreneurs could not deal with $[27,28]$.

The input of wind energy in the regulated market from 2009, as part of the policy of diversification of the energy matrix and purchase priority for renewable sources, resulted in a new milestone for the integration of this technology in the Brazilian electric sector. Since then, wind power projects accounted for $50 \%$ of the generation capacity of electricity contracted ${ }^{1}$, with energy prices increasingly competitive, approaching the average value of conventional power plants.

With the beginning of operation of the negotiated projects in the regulated market, installed capacity of wind power will reach $8.1 \mathrm{GW}$ in 2016, which corresponds to 5.5\%

\footnotetext{
${ }^{1}$ Measured in power generation capacity,rather than physical. Takes into consideration lower capacity factor of wind power compared with other energy sources.
} 
of the total. The completion of the first wind power auction and the continued participation of wind energy in annual power negotiating bids stimulated the arrival of new international companies and the opening of new turbine factories in Brazil. Until 2007 there was only one manufacturer of wind turbines with factories in operation in Brazil. At the end of 2011, that number had risen to five, and it is expected that by the end of 2013 it will reach eight, accounting for factories in construction and agreements between companies and governments. Besides these factories, the number of component manufacturing plants (blades and towers) is increasing. The number of companies providing services and consulting increases as well.

The increasing number of large companies manufacturing wind turbines denotes the attractiveness of this market. In November 2011 the North American consulting company Ernst \& Young has published an index of RET attractiveness in many countries. In this report, Brazil was the 10th most attractive country for investments in renewable energy and the 9th most attractive market for investment in wind energy [29]. In fact, after the financial crisis of 2008-2009, which compromised traditional markets in Europe and North America, international companies are starting to turn to markets on the rise such as Brazil. The negotiation of increasing wind power capacities in auctions has justified the installation and expansion of equipment factories in the country, which not only target the domestic market but also wind turbines exports to the promising Latin American market.

The rapid development of the Brazilian wind industry and the opening of new businesses and factories in the country justify the assessment of social and economic effects that wind energy growth will bring to the economy.

\section{METHODS}

Employment assessment has targeted jobs created in activities directly related to wind power production. We quantified employment in wind turbine manufacturing, wind farm construction, and O\&M. All jobs are quantified in jobs-year ${ }^{2}$.

Employment data were obtained through interviews with companies from the different activities. We interviewed 20 representatives of companies that act throughout the whole life cycle of a wind power project: manufacturing of major components (nacelle, blades and towers), transport of equipment, construction and installation, O\&M, project planning and management, environmental agencies, and industry associations. We also collected onsite data for 6 wind farms in operation and 4 in different stages of construction.

We calculated the amount of jobs occupied in the activities with the following assumptions:

o For manufacturing activities, we divided the total employment at annual full production capacity ${ }^{3}$ by the maximum amount of product, in MW;

o For construction activities, we normalized the amount of workers in construction and installation for a period of one year. The average construction period was found to be 18 months.

\footnotetext{
${ }^{2}$ Jobs-year, or per capita-year, are considered as the job that an average worker would have in one year. It normalizes temporary jobs throughout the project's life cycle. For jobs that take place for more or for less than one year, jobs-year should be calculated as months actually worked divided by twelve months (one year).

${ }^{3}$ Wind turbines are manufactured by demand. The manufacturing plant has a maximum output capacity (for example, in blade sets per year), and we considered the total employees needed to achieve this full production.
} 
o For O\&M activities we considered an average of workers per MW installed based on operating wind power plants. It involves not only the workers strictly responsible for O\&M, but also the ones responsible for the maintenance of the facilities, such as security guards, cookers, cleaners, and drivers ${ }^{4}$.

Employment rates calculated per MW were assumed to be static. Thus, employment rates for the future wind power deployment were considered to be equivalent to the figures obtained from the interviews. That is, technology's evolution was ignored. Nevertheless, the approach differs from previous ones because instead of using the annual installed capacity as a reference for measuring job creation [6,8-10,30], production capacity was adopted, i.e., potential for job creation, considering wind turbines domestically produced. This approach also allows building imports and exports scenarios and, thus, analyse the effects of wind power development on employment in the domestic industry.

The potential for job creation from 2012 to 2016 was modelled, accounting for wind power projects already contracted. Together, these projects will account to $6.7 \mathrm{GW}$ of new power plants, summing up to $8.1 \mathrm{GW}$ operating in 2016.

\footnotetext{
${ }^{4}$ We assumed that, for each year of operation, the same amount of jobs-year would be needed, and thus the amount of jobs-year occupied throughout the life cycle of the wind farms would be the multiplication of jobs occupied by the lifetime of the project.
} 


\section{RESULTS}

The quantification of direct jobs in wind power was performed with a different approach than the ones in the literature. For this calculation, information was sought among the companies interviewed about their production capacity and generated jobs. Indexes consisted of created jobs for average production capacity ${ }^{5}$ of equipment manufacturing activities, wind farm construction, and plants O\&M. All indexes reflect potential job creation with $100 \%$ nationalization of major components. The construction of indexes disaggregated by activity and product allows for the assessment of impacts of imported equipment on domestic jobs. In these conditions, jobs would sum 11.7 jobs-year/MW installed, as illustrated in Figure 2. Table 2 shows a comparison between this calculated index and others found in previous works.

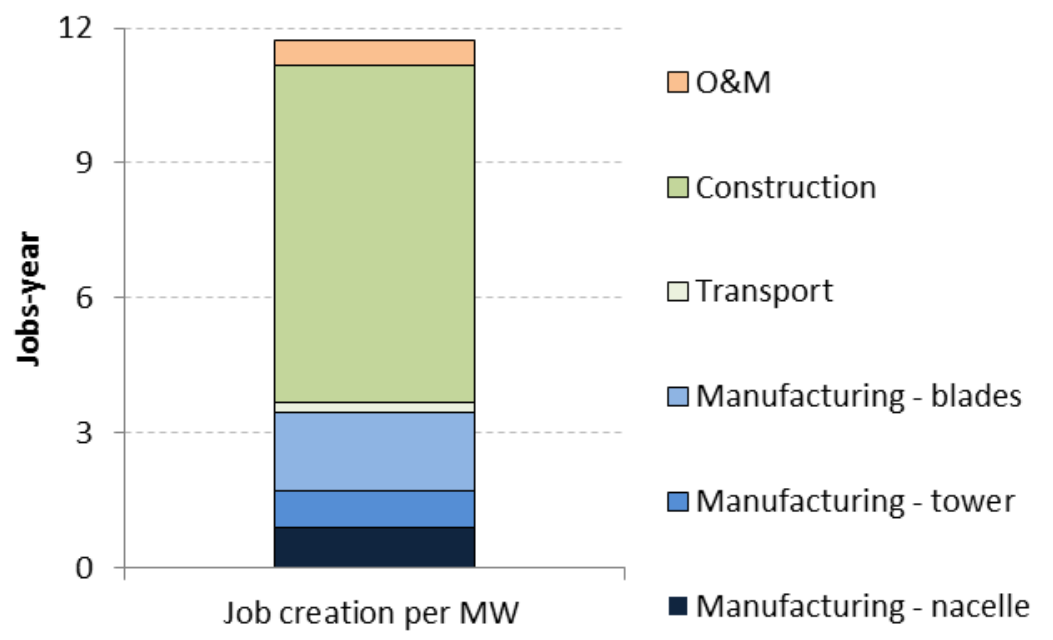

Figure 2. Employment rates for different stages of an average wind farm in Brazil

We assumed for simplification that the increase of capacity in a year would create, in the same year, the related jobs in manufacturing, construction and O\&M. Although usually jobs in manufacturing and construction are created one to two years prior the operation of the project, this difference was ignored in the analysis. For the first year of the project then, the manufacturing stage would account for $30 \%$ of total employment generation, while construction would sum up to $65 \%$, and O\&M, only $5 \%$ of the jobs created. However, while employment in manufacturing and construction stages would only occur during the first year of the project, jobs created in O\&M will persist for the whole lifetime of the projects, usually for 20 years $^{6}$.

Table 2. Comparison of this study's employment index, in the first row, with other indexes found in previous works

\footnotetext{
${ }^{5}$ Previous studies have divided jobs occupied not by production capacity, but rather by installed capacity in the studied year.

${ }^{6}$ Although contracts signed guarantee power purchase for 20 years, project developers interviewed believe that, in most cases, the wind farm wouldn't be decommissioned, but rather upgraded and continue to operate.
} 


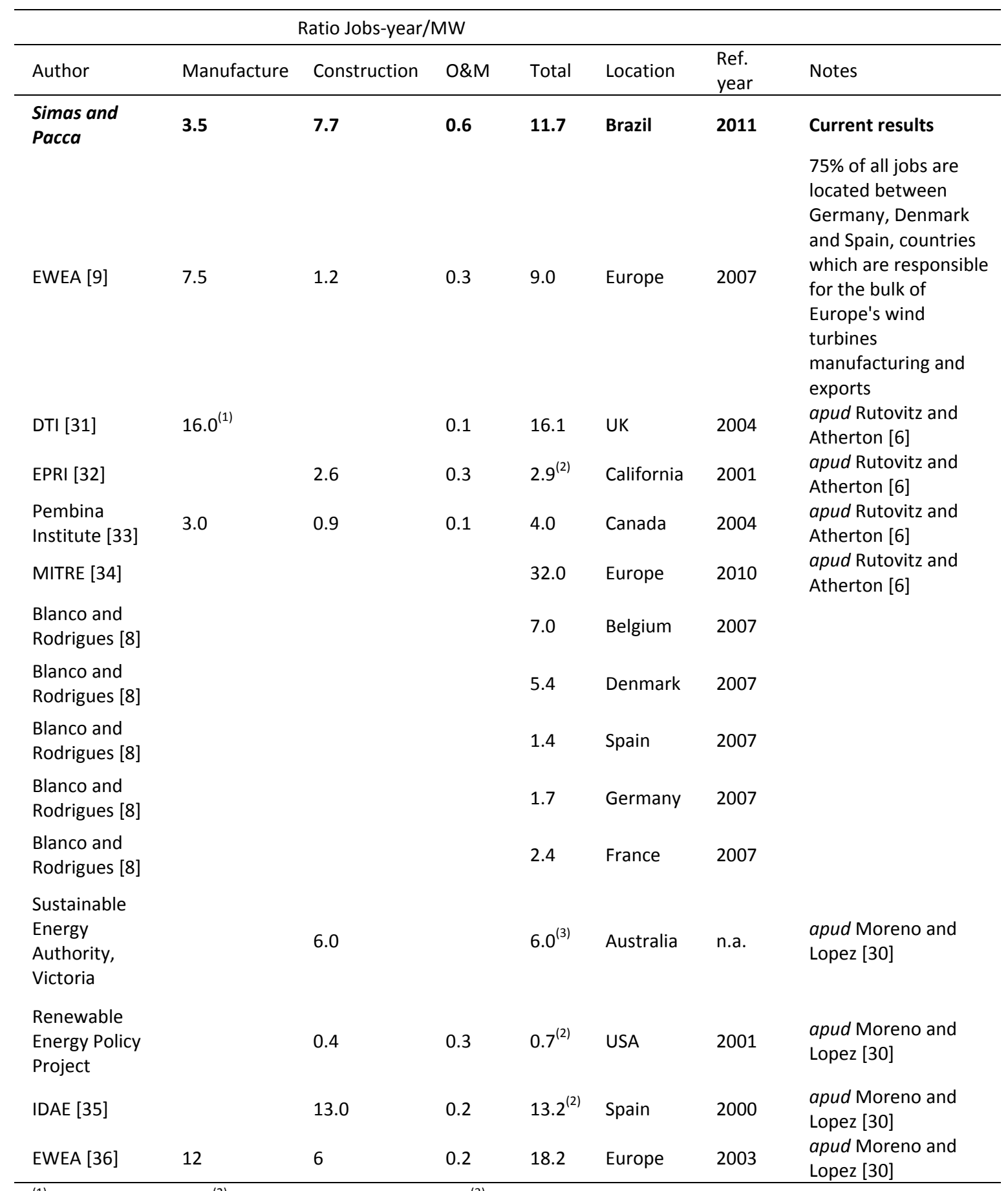

${ }^{(1)}$ Includes construction; ${ }^{(2)}$ Does not include manufacturing; ${ }^{(3)}$ Only construction

When looking at jobs created at the end of the analysed period, the importance of O\&M escalates. Between 2012 and 2016, wind power can create almost 90,000 jobs-year in manufacturing, construction and O\&M. Looking at the cumulative jobs at the end of the time period, manufacturing and construction decrease participation to $26 \%$ and $58 \%$, respectively, while O\&M participation in overall cumulative employment, in jobs-year, increases to $16 \%$. Results are shown in figure 3. 


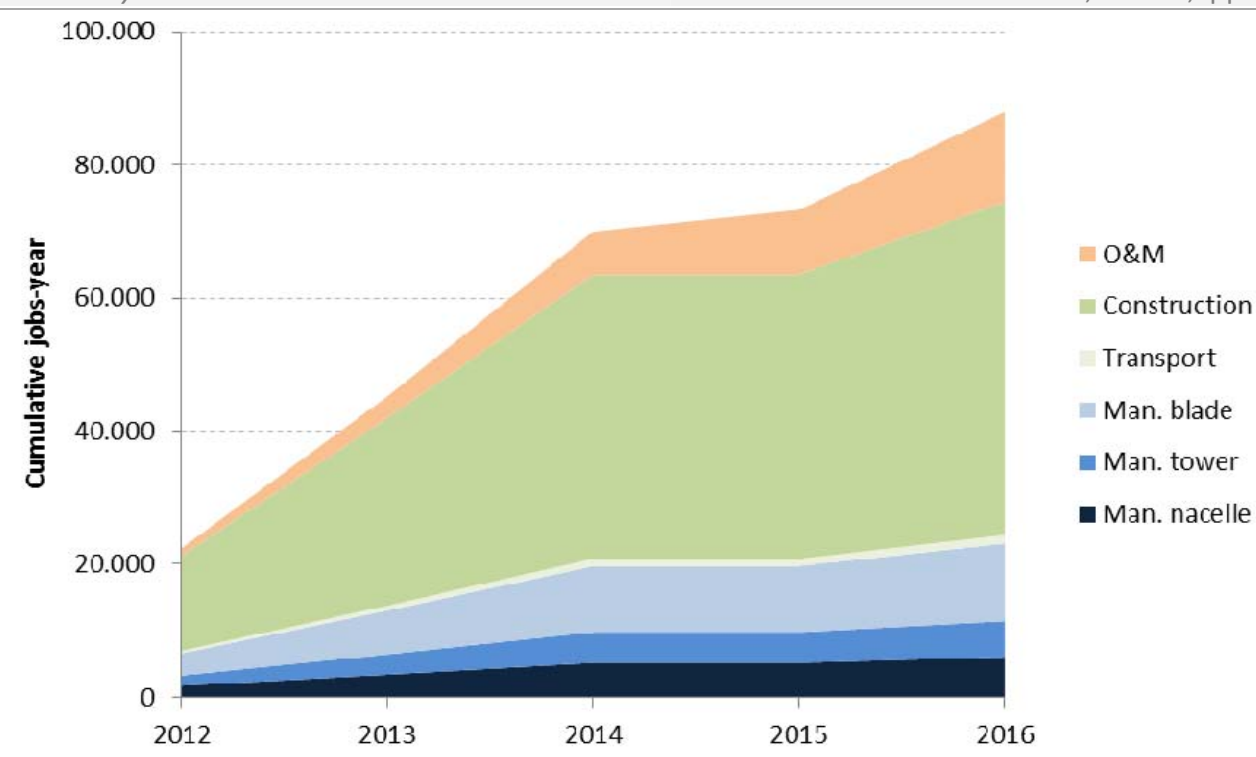

Figure 3. Cumulative employment created by wind power in Brazil between 2012 and 2016

\section{DISCUSSION}

Wind power can generate thousands of new jobs in Brazil. Most direct jobs are generated in construction of wind farms, as opposed to previous results found in studies on employment in the wind power sector in Europe, in which manufacturing corresponds to the bulk of new employment [7-10]. That happens because previous studies have failed to separate manufacturing for exports from those that occur for domestic projects. Also, labour intensity in Brazil is higher than in previous assessed countries.

Over a half of the total jobs are found in the construction stage, showing the potential to create local jobs, bringing social and economic development to communities located near the installation site. Because wind power is less concentrated than traditional power plants, wind farm construction may have a positive impact on several communities. That is even more important when it is seen that most of the wind power potential in Brazil is located in rural areas, usually with low economic activity and scarce opportunities of economic development.

In addition to onsite direct jobs, there are other benefits perceived by local population and entrepreneurs. More visible is the benefit to owners of the land in which the wind farm is installed. Unlike many other energy sources, the owners, in general, are not displaced from their land, but instead sign rental agreements with wind energy investors. The contracts begin to count from the anemometers installation, which can last up to three years until the commissioning of the project. During this period, the owners receive a monthly or yearly rent for the land, and may carry on their economic activities. As wind farms are often located in rural areas, these activities are usually farming and/or livestock. Obtaining extra income allows investment in improvements in production and facilitates access to loans. During the construction stage, due to movement of machinery and civil works, much of the area occupied by the wind farm undermines the continuity of economic activities. However, after the construction period, which usually lasts up to 18 months, most areas can be re-occupied with the previous activities. Common activities in wind farms in operation in the Northeast and South of Brazil include livestock, commercial production of pine trees, fish and shrimp farming, rice, and coconuts production. 
During the construction phase other benefits besides direct employment for the actual site development arise. Due to the increasing volume of on-site workers, local residents are benefited by the consumption of local goods and services, especially food and lodging. The benefits are even greater when the plant is located in areas of low economic development. This is the case of wind farms that are being installed in the interior of Rio Grande do Norte State, in the Northeast, in the municipalities of Parazinho and João Câmara. Together, these two regions concentrate 45 wind farms with an installed capacity of $1.25 \mathrm{GW}$.

The construction stage demands large amounts of water due to the high consumption of concrete. In semi-arid regions, such as the interior of the Northeast, the wells opened for construction purposes can be left for residential water supply. This is the case of the Morro dos Ventos wind farm in João Câmara municipality, where the wells drilled by the company will be managed by the local government. Best practices in project management like this are innovative in terms of the relation between investors and the community, and are gaining more and more concurrence between entrepreneurs, becoming an activity with potential for local development.

\section{CONCLUSION}

Benefits of investments in renewable energy and climate change mitigation go beyond the reduction of GHG emissions. Ancillary benefits include technology transfer, reduction of emissions of other pollutants and job creation, often called green jobs. It is known that job creation reflects on social, economic, and environmental aspects. Therefore, it can be an indicator of the social performance of energy projects.

Wind power has experienced expressive growth over the past few years, and contracted wind projects will increase Brazilian installed capacity from $1.4 \mathrm{GW}$, at the end of 2011, to $8.1 \mathrm{GW}$ in 2016. The present article evaluated the consequences of this rapid growth on employment in Brazil. Jobs were quantified in manufacturing, installation and operation activities, observing national characteristics and national manufacture of major components.

Results from the study show that the estimated wind power growth will generate over 80,000 jobs-year. At the end, $58 \%$ and $16 \%$ will be created in the construction and O\&M stages respectively, which have high level of local employment, bringing social and economic benefits to the installation sites.

It is important to highlight that employment on manufacturing quantified in this study are only valid if major components are produced in Brazil. However, the reduction of wind power prices achieved in competitive auctions may lead to the use of imported materials, as domestic industry is still gaining momentum. To achieve the benefits of job creation, the national industry must be strengthened and there must be incentives for the consumption of national inputs, as well as incentives for RET.

\section{ACKNOWLEDGEMENTS}

We would like to thank to CAPES and to CNPq, the Brazilian research foundations, and to the Life Cycle Assessment Laboratory of the Institute of Energy and Environment of the University of Sao Paulo. We would also like to thank all the companies and persons who collaborated with data for this research, and to the Brazilian Wind Energy Association (ABEEólica), which helped us to contact the companies. 


\section{REFERENCES}

1. Frankhauser, S., Sehlleier, F. and Stern, N., Climate change, innovation and jobs, Clim. Policy, Vol. 8, No. 4, pp. 421-429, 2008. (http://dx.doi.org/10.3763/cpol.2008.0513)

2. The White House, Remarks by the President to the Nation on the BP Oil Spill. 2010. [Online]. Available:

http://www.whitehouse.gov/the-press-office/remarks-president-nation-bp-oil-spill. [Accessed: 15-Jun-2010].

3. UNEP, ILO, IOE, and ITUC, Green Jobs: Towards Decent Work in a Sustainable, Low-Carbon World, Worldwatch Institute, Washington DC, 2008.

4. Wei, M., Patadia, S. and Kammen, D. M., Putting renewables and energy efficiency to work: How many jobs can the clean energy industry generate in the US?, Energ. Policy, Vol. 38, No. 2, pp. 919-931, Feb. 2010. (http://dx.doi.org/10.1016/j.enpol.2009.10.044)

5. Goldemberg, J., Coelho, S. T. and Lucon, O., How adequate policies can push renewables, Energ. Policy, Vol. 32, No. 9, pp. 1141-1146, 2004. (http://dx. doi.org/10.1016/S0301-4215(03)00077-6)

6. Rutovitz, J. and Atherton, A. Energy Sector Jobs to 2030: A Global Analysis, Prepared for Greenpeace International by the Institute for Sustainable Futures, University of Technology, Sidney, 2009.

7. Lehr, U., Nitsch, J., Kratzat, M., Lutz, C., and Edler, D., Renewable energy and employment in Germany, Energ. Policy, Vol. 36, No. 1, pp. 108-117, 2008. (http://dx.doi.org/10.1016/j.enpol.2007.09.004)

8. Blanco, M. I. and Rodrigues, G., Direct employment in the wind energy sector: An EU study, Energ. Policy, Vol. 37, No. 8, pp. 2847-2857, 2009.

(http://dx.doi.org/10.1016/j.enpol.2009.02.049)

9. EWEA, Wind at Work - Wind energy and job creation in the EU, European Wind Energy Association, Brussels, 2008.

10. Dalton, G. J. and Lewis, T., Metrics for measuring job creation by renewable energy technologies, using Ireland as a case study, Renew. Sust. Energ. Rev., Vol. 15, No. 4, pp. 2123-2133, 2011. (http://dx.doi.org/10.1016/j.rser.2011.01.015)

11. Laitner, S., Bernow, S. and DeCicco, J., Employment and other macroeconomic benefits of an innovation-led climate strategy for the United States, Energ. Policy, Vol. 26, No. 5, pp. 425-432, 1998. (http://dx.doi.org/10.1016/S0301-4215(97)00160-2)

12. Río, P. and Burguillo, M., Assessing the impact of renewable energy deployment on local sustainability: Towards a theoretical framework, Renew. Sust. Energ. Rev., Vol. 12, No. 5, pp. 1325-1344, 2008. (http://dx.doi.org/10.1016/j.rser. 2007.03.004)

13. Bergmann, A., Hanley, N. and Wright, R., Valuing the attributes of renewable energy investments, Energ. Policy, Vol. 34, No. 9, pp. 1004-1014, 2006. (http://dx.doi.org/10.1016/j.enpol.2004.08.035)

14. Tourkolias, C. and Mirasgedis, S., Quantification and monetization of employment benefits associated with renewable energy technologies in Greece, Renew. Sust. Energ.

Rev., Vol. 15, No. 6, pp. 2876-2886, 2011. (http://dx.doi.org/10.1016/j.rser.2011.02.027)

15. Goldemberg, J., Leapfrog energy technologies, Energ. Policy, Vol. 26, No. 10, pp. 729-741, 1998.

16. Zerriffi, H. and Wilson, E., Leapfrogging over development? Promoting rural renewables for climate change mitigation, Energ. Policy, Vol. 38, No. 4, pp. 1689-1700, 2010. (http://dx. doi.org/10.1016/j. enpol.2009.11.026) 
17. Carley, S., Lawrence, S., Brown, A., Nourafshan, A. and Benami, E., Energy-based economic development, Renew. Sust. Energ. Rev., Vol. 15, No. 1, pp. 282-295, 2011. (http://dx.doi.org/10.1016/j.rser.2010.08.006)

18. Nguyen, K. Q., Alternatives to grid extension for rural electrification: Decentralized renewable energy technologies in Vietnam, Energ. Policy, Vol. 35, No. 4, pp. 2579-2589, 2007. (http://dx. doi.org/10.1016/j.enpol.2006.10.004)

19. Río, P. and Burguillo, M., An empirical analysis of the impact of renewable energy deployment on local sustainability, Renew. Sust. Energ. Rev., Vol. 13, No. 6-7, pp. 1314-1325, 2009.

20. Singh, V. and Fehrs, J., The work that goes into renewable energy, Renewable Energy Policy Project, Center for Renewable Energy and Sustainable Technology, Washington DC, 2001.

21. Sastresa, E. L., Usón, A. A., Bribián, I. Z. and Scarpellini, S., Local impact of renewables on employment: Assessment methodology and case study, Renew. Sust. Energ. Rev., Vol. 14, No. 2, pp. 679-690, 2010. (http://dx.doi.org/10.1016/j.rser.2009.10.017)

22. Cepel, Atlas do Potencial Eólico Brasileiro, Centro de Pesquisas de Energia Elétrica, Rio de Janeiro, 2001.

23. Amarante, O. A. C., Schultz, D. J., Bittencourt, R. M. and Rocha, N. A., Wind/Hydro complementary seasonal regimes in Brazil, DEWI Magazin, Vol. 19, pp. 79-86, 2001.

24. Brazilian Agency for Electric Energy, Atlas de Energia Elétrica do Brasil, 2 ed., Agência Nacional de Energia Elétrica, Brasilia, 2005.

25. Denault, M., Dupuis, D. and Couture-Cardinal, S., Complementarity of hydro and wind power: Improving the risk profile of energy inflows, Energ. Policy, Vol. 37, No. 12, pp. 5376-5384, Dec. 2009. (http://dx.doi.org/10.1016/j. enpol.2009.07.064)

26. Brazilian Ministry of Mines and Energy, Benefícios do Proinfa, 2012. [Online]. Available: $\quad$ http://www.mme.gov.br/programas/proinfa/menu/beneficios.html. [Accessed: 29-Jul-2011].

27. Ferreira, H. T., Energia eólica: Barreiras para sua participação no setor elétrico brasileiro, M.Sc. Thesis, USP Electrotech. Energ. Inst., Sao Paulo, 2008.

28. Nogueira, L. P. P., Estado atual e perspectivas futuras para a indústria eólica no Brasil, M.Sc. Thesis, UFRJ Grad. Res. Eng. Inst., Rio de Janeiro, 2011.

29. Ernst \& Young, Renewable energy country attractiveness indices - Vol. 31, London, Nov-2011.

[Online].

Available:

http://www.ey.com/Publication/vwLUAssets/Renewable_energy_country_attractiven ess_indices_-_Issue_31/\$FILE/EY_RECAI_issue_31.pdf. [Accessed: 01-Dec-2011].

30. Moreno, B. and López, A. J., The effect of renewable energy on employment. The case of Asturias (Spain), Renew. Sust. Energy Rev., vol. 12, pp. 732-751, 2008. (http://dx.doi.org/10.1016/j.rser.2006.10.011)

31. DTI, Renewable Supply Chain - Gap Analysis. Summary Report. 2004.

32. EPRI, California Renewable Technology Market and Benefits Assessment. California Energy Commission, 2001.

33. Pembina Institute, Canadian Renewable Electricity Development: Employment Impacts. Prepared for Clean Air Renewable Energy Coalition. 2004.

34. MITRE, MITRE Overview Report 2003: Meeting the targets and putting renewables to work. European Commission, 2003.

35. IDAE, Plan de Energías Renovables en España 2005-2010. 2005.

36. EWEA, Wind energy - The facts. Industry and employment, Vol. 3. European Wind Energy Association, Brussels, 2004. 